INTENSIVE JOURNAL

http://ojs.uniska-bjm.ac.id/index.php/EJB

E-ISSN 2620-4746

October 2021, Vol 4 No.2

\title{
AN APPROACH OF ENGLISH TEACHING FOR AUTOMOTIVE AND VEHICLE ENGINEERING STUDENTS
}

\author{
Purnama Ayu \\ University of Palangkaraya \\ misspurnamaayu@gmail.com \\ Wahyuningsih Usadiati \\ University of Palangkaraya \\ wahyu.usadiati@edu.upr.ac.id \\ Elanneri Karani \\ University of Palangkaraya \\ elannerikarani@gmail.com
}

Abstract

English for Specific Purposes (ESP) is generally interpreted as an approach to learning English based on the goals/needs of the learner. In the context of learning English in Indonesia, both at secondary and tertiary schools, especially for automotive students, the ESP approach is a popular choice. The application of this approach is in line with the government policy in the field of education which emphasizes the purpose of learning English, namely to improve the ability of students to use English, especially for academic and professional career needs with an emphasis on reading skills that allow students to understand authentic material topics according to their majors. effectively. This article puts forward a theoretical study of the basic concepts of ESP including its definition and role as a learning approach, along with related issues including needs analysis as the main feature of ESP, syllabus, learning objectives, materials, methodology, and evaluation of ESP-based English learning.

\section{Keywords: ESP \& ELT}




\section{INTRODUCTION}

English for particular purposes (ESP) instruction is designed to prepare students with a specified level of English proficiency for a specific circumstance in which the language will be used, referred to as target needs. Since it includes instructional objectives, resources, and procedures that are built with learners' needs and prospective interests in mind, ESP has grown to become one of the most significant areas of English foreign language training since the early 1960s. Nowadays, ESP is not just used with individuals who have achieved a basic level of English competence or with those who are studying English for specific goals, but also with English language learners who are learning general English.

\section{THE DEFINITION OF ESP}

ESP has a variety of definitions. Some individuals think of ESP as merely the teaching of English for any purpose. Others, on the other hand, are more particular, identifying it as the teaching of English for academic objectives, the teaching of English for vocational or professional goals, or the teaching of English for non-native English speakers learning English for specific purposes.

Hutchinson and Waters (1987, p.19) define ESP as a technique of language education in which all content and method decisions are made based on the learners' motivation to learn. Robinson (1991, p.1) saw ESP as a business combining education, training, and practice, based on three major realisms of knowledge: language, pedagogy, and the students'/participants' specialist area of interest. ESP, according to Richards \& Rodger (2001, p.107), is a movement that aims to meet the language needs of learners who require English to perform specific roles (e.g., student, engineer, nurse) and who need to acquire content and real-world skills through it rather than mastering the language for its own sake.

Strevens (1998) provided a more detailed description of ESP, describing it as a subcategory of the general category of special purpose language education. He went on to say that the concept of ESP is required to differentiate between four absolute and two changeable features. The following are the four absolute properties of ESP in terms of English language teaching:

1. designed to meet specific learner needs,

2. related to content (i.e., in its themes and topics) to specific disciplines, occupations, and activities,

3. centered on the language appropriate to those activities in syntax, lexis, discourse, semantics, and so on, and 4. differentiated from General English

While the two variable characteristics of ESP may be, but are not always:

Intensive Journal, Vol. 4(1), 2021 
1. limited in terms of the language skills to be learned (e.g., reading only);

2. not taught in accordance with any pre-determined methodology.

Strevens (1998), pp.1-2 Dudley-Evans (1998) significantly improved Strevens' definition of ESP by removing the absolute characteristics that ESP is "in contrast with 'General English,' and has revised and increased the number of variable characteristics. As a result, Dudley-Evans' definition of ESP in terms of absolute and variable characteristics is as follows: Characteristics that are absolute

1. ESP is defined to meet specific needs of learners;

2. ESP employs underlying methodology and activities of the discipline it serves; and

3. ESP is focused on the language appropriate to these activities in terms of grammar, lexis, register, study skills, discourse, and genre.

Characteristics That Change

1. ESP may be related to or designed for specific disciplines;

2. ESP may use a different methodology than General English in specific teaching situations; and

3. ESP is likely to be designed for adult learners, either at a tertiary level institution or in a professional work situation. It could, however, be for secondary school students,

4. ESP is typically designed for intermediate or advanced students,

5. Most ESP courses assume a basic understanding of the language systems (Dudley-Evans, 1998)

It is widely agreed that the most fundamental account of ESP is that any decision made in designing language teaching programs should be based on the needs of the learners to learn English. In relation to this, the term "specific" in ESP has taken on new meaning as the field evolves. In the 1960s, it referred to a list of technical vocabulary for a specific field or profession (Hutchinson \& Waters, 1987, p.9; Dudley-Evans \& St John, 1998, p.1; Smoak, 2003, p.23). From the 1980s to the present, it has referred to the needs and interests of the students (Stevens, 1988, p.2).

According to the definitions provided, ESP is understood to be about preparing learners to use English in academic, professional, or workplace settings where the language will be used. In ESP, English is learned not for its own sake or to gain a general education, but to smooth the path to entry or to improve linguistic efficiency in specific environments (Basturkmen, 2006, p.18).

\section{ESP AS AN APPROACH TO LANGUAGE TEACHING}

Dudley-definition, Evan that's which consists of three absolute and five variable characteristics, represents an insight that ESP can but does not have to be concerned with a specific discipline, nor does it have to be aimed at a specific age group or ability

Intensive Journal, Vol. 4(1), 2021 
range. It should simply be regarded as a method of teaching, or as Dudley-Evans refers to as a "attitude of mind." This is a similar assumption to that proposed by Hutchinson and Waters (1987, p.19), who state that ESP is a method of language teaching in which all content and method decisions are based on the learner's reason for learning. The meaning of the word "special" in ESP confirms the rule of ESP as an approach to language teaching in which content and method are applied based on the learner's learning needs. A better way to put it is It is the goal for which learners learn a language, rather than the nature of the language that is being learned, that is referred to as specialized aim (Mackay \& Mountford, 1978). Therefore, ESP has often been used to assist language learners in coping with the characteristics of their native language or in developing the competences necessary to perform in a discipline, career, or workplace for which they wish to acquire English. The ESP approach has been widely used in the context of teaching English in Indonesia at both the secondary and tertiary school levels, particularly for students from non-English-speaking backgrounds.

This is in accordance with the Government's Education Policy, which emphasizes that the goal of teaching English at the tertiary school level, particularly for students who do not study in an English department, is to improve their ability to use English for academic and professional purposes, particularly for reading their textbooks in their academic work, as well as to improve their ability to communicate effectively in English with others. This suggests that reading ability has been given the highest priority in English language training because it is the most effective way for students to learn in their subject of study. It is also related to what Hutchinson and Waters state that the specific purpose most common within the participant universities is the reading of specialist literature in English, and that the emphasis is largely on general course content to cover common problems, such as reading strategies, rather than specific discourses, according to the student subject specialization, and that the reading of specialist literature in English is the most common specific purpose within the participant universities. The authors go on to explain that, as a result, there is a consensus within the teaching and learning process to concentrate on the teaching of reading strategies through authentic materials and the use of the native language in spoken classroom discourse, while focusing on the teaching of grammar on the minimum necessary for understanding academic texts is the focus of the authors (Hutchinson \& Waters, 1987). Since reading is the most stressed skill in English instruction, this approach will also include the teaching of other language skills such as speaking, listening, and writing, all of which will be enhanced by the incorporation of language components.

Intensive Journal, Vol. 4(1), 2021 
As stated previously, the goal of ESP courses is to prepare students with a certain level of English proficiency for a situation in which the language will be used, or target needs (Sujana, 2005). Therefore, for non-English department students at Indonesian universities, being able to communicate in English and to use English to learn their subjects effectively are considered to be the most important benefits of having English. While English is often taught as a subject matter in schools, it is also used as a tool for students to learn about their fields of study. In this context, English is not simply a subject matter to be learnt, as it is often taught as one of the mandatory courses in the curriculum. It is a fact that the English language proficiency program (ESP) combines subject matter and English language instruction in a way that students are able to apply what they learn in their English classes right away in their studies, whether they are in economics or education or accounting or business management or the sciences or Islamic studies or tourism. As a result, their knowledge and expertise in their respective subject areas is extremely beneficial to their English language learning efforts.

It is clear from the information presented above that the foundation of ESP is the simple question of what the students learn English for, and that the answer to this question relates to the learners, that is, their needs, the language required, that is, the language skills they must master and how well, and the learning context, which refers to the genres they must master either for comprehension or production purposes, and the learning context is defined as the genre in which they must master either for comprehension or production (Dudley-Evans, 2001, p.225-238).

\section{NEEDS ANALYSIS AS A KEY FEATURE OF ESP}

In ESP, needs analysis is the most common characteristic, and it is generally regarded as criteria or a key feature of ESP. ESP was previously focused primarily on target or end-of-course requirements, and it is usually to take into account learners' initial needs, which may include learning needs, in order to be effective. ESP needs analysis serves three main purposes as criteria: first, it allows for a more diverse range of input into the content, design, and implementation of an educational program; second, it allows for more efficient use of limited resources; and third, it allows for more efficient use of limited resources. Second, it can be used in the development of goals, objectives, and content. As for the third reason, it can be used to assess the effectiveness of an existing program (Richards, 1996).

A series of techniques for establishing the parameters of a course of study is termed as a need analysis procedure (Nunan, 1988). Needs analysis, in its broadest sense, is a technique for gathering information on the requirements of learners. The term 'needs' in the context of 'needs analysis' can refer to a variety of distinct things.

Intensive Journal, Vol. 4(1), 2021 
Essentially, it is the study or employment requirement that the learner is expected to be capable of performing at the conclusion of their course. This is an example of a goal-oriented definition of requirements. In this context, the term "needs" may be more aptly translated as "objectives." Widdowson goes on to say that, in addition to being objective, it also relates to the actions that learners must take in order to genuinely learn the language. This might be interpreted as a process-oriented statement of requirements that are related to transitional behavior (Widdowson, 1990). Additionally, needs might be described as what the user institution of society as a whole considers to be required or desirable to be learned via a program of a language education institution (Mackay \& Mountford, 1978).

Target needs and learning needs, according to Hutchinson and Waters (1993), are two distinct types of requirements. Target needs concern what learners must perform in the target scenario, whereas learning needs concern what learners must learn in the target situation. NECESSITIES, LACKS, and WANT are three useful concepts to consider when identifying target needs. Necessities are the kind of needs that are dictated by the demands of the target scenario, such as food and shelter. This indicates that the most important thing for learners to understand is how to function well in the goal circumstance. There are gaps between the target competency and the existing proficiency of learners, which are known as deficiencies. Lacks can only be organized when teachers or course designers have determined the demands of the students they are teaching. Concern yourself with the awareness of the requirements that define the ESP circumstance. Awareness is a type of perception that might differ depending on the individual's point of view or point of view. When learners have a comprehensive understanding of the requirements of the target situation, and they already have a specific understanding of their own deficiencies, their perceptions may not always align with the perceptions of other interested parties such as teachers, course designers, or sponsors. As a result, the optimal the desires of all the groups engaged in deploying ESP must be reflected. The information and abilities that learners will require in the target context are referred to as learning needs. If the beginning point in ESP is referred to as "lacks," and the destination is referred to as "necessities and wants," then the path that leads from the starting point to the destination is referred to as "learning requirements."

Based on all of the categories provided above, learners are considered to be the heart of any program. They are no longer the object of any lesson; rather, they are the subject of the instruction. Their requirements will drive the specification of syllabus content, which will include considerations for things such as language abilities, structures, functions, concepts, topics, themes, scenarios, and interlocutors as well as other factors. Because the selection is made based on the needs of the learners, there is a good chance that there will be some changes from learner group to learner group.

Intensive Journal, Vol. 4(1), 2021 
Different types of learner requirements will be addressed in a variety of ways. In particular, and once again, in the context of the requirements for which the reasons for which they are studying English are predicated.

A needs assessment is typically carried out before to, or at the very beginning of, a training course. The first step in doing a requirements analysis is to determine what data will be gathered, when it will be collected, who will collect it, how it will be collected, and for what objectives it will be collected. The information about learner requirements that has been gathered naturally falls into two distinct areas. The first includes primarily biographical information, but the second is more personal in nature, referring to the learner's choices and impressions of their own needs and wants (Nunan, 1988).

Techniques for individuals involved in data collection and course design can be classified as either formal or informal, depending on their purpose and setting. For example, formal procedures such as standardized interviews and competence assessments are used, whereas informal strategies such as classroom observation and a self-relating scale are used by learners to evaluate their own learning activities are used. Questionnaires, comprehensive interviews, observation, and newspaper advertisements are the four strategies used to investigate demands. In comparison to other methods of acquiring useful information, the questionnaire is quite inexpensive. It is necessary to employ a systematic approach in order to obtain acceptable data from a questionnaire.

For example, it is recommended to mail out questionnaires that the learners are already aware are on their way, along with sufficient explanation of what they are for, to ensure that the entire class understands what they are for. Furthermore, the language in which the questionnaires are written should be at a level that learners can comprehend, rather than being as plain as possible as could be the case with a recommendation (Yalden, 1987).

Interviewing is the second tactic to use. When interviews are conducted rather than questionnaires, the needs analyst has greater control. The other advantage of using an interview technique is that it allows you to provide the respondents with linguistic clarification while still recording their responses and justifications. Additionally, the interviewer can follow up on any fascinating new lines of inquiry that arise while still having a pre-planned agenda to refer back to.

Fitzgerald presents a set of guidelines for the development of questionnaires and interview questions, which include:

1. The historical context. Biographical details, as well as educational level, valuable language learning experience, and current competency in the target language, are all required for consideration.

Intensive Journal, Vol. 4(1), 2021 
The second type of language style is one in which questions are applied to determine whether learners learn best through talks, mastering existing skills before attempting new ones, studying grammar and having sufficient grasp of important vocabulary before reading a book, and so on.

3. The requirement for a foreign language. It relates to the reasons that learners choose to enroll in a language course, as well as the language abilities that they wish to acquire and the situations in which the language will be used by learners.

In more depth, Yalden (1987) specifies key components that must be present in questionnaires and interviews in order to be valid: (1) the purposes for which learners hope to acquire a target language, (2) the context in which they will want to use the target language, (3) the roles of learners and their interlocutors, (4) the communicative events in which learners will participate, and (5) the language functions involved or what learners will need to know about the target language

for learners to be able to do with or through using the target language, (6) the notions involved or what learners will need to know about, (7) the skills involved in putting discourse and rhetorical skills together, (8) the variety or varieties of the target language that will be required, and the levels in either spoken or written language that learners will need to achieve.

Furthermore, a questionnaire may include some questions or statements, such as the one developed and used by Richards for non-English department students in the Institute of Language Teaching and Learning, University of Auckland New Zealand. This questionnaire is divided into eleven sections, which are as follows. The following sections are included: (1) overview of difficulties encountered; (2) general statement; (3) speaking and listening skills; (4) speaking skills; (6) writing skills; (7) reading skills; (8) skills the students would like to improve; (9) support available; (10) catering for ESL students; and (11) additional comments (Richards, 1996, p.80).

Because the coherent objectives and subsequent decisions on course content of a course are established on the basis of the needs analysis, it is highly recommended that this procedure be completed as much as possible before any course or series of courses begins, and that it be repeated throughout the life of each course during its duration (Richterich, 1972).

\section{DESIGNING SYLLABUS FOR AUTOMOTIVE COURSE}

From the data findings on teacher's ways of using textbooks, both teachers used the main textbook to accompany the external textbook as a major book to explain the material inside the classroom. They both used the main textbook as a framework of learning. Because of the lack of material inside the textbook, the teachers made some adaptation when they were teaching inside the classroom. The types of

Intensive Journal, Vol. 4(1), 2021 
adaptation that the teacher used was based on what the teacher saw from the students' need. Before they applied the whole textbook material into the classroom, they needed to evaluate the textbook and made some adaptation to make their students felt comfortable to learn inside the classroom. It is obvious that the teacher made adaptation by adding material, and modifying the task was to help the students in understanding the lesson easily. This is in line with Aminuddin (2009) and Diniah (2013), who found that adaptations of a textbook that meet the students' needs can improve students' skills in learning English.

Besides, adapting textbooks is one of the abilities that teachers should have. According to Richards (2001), Spratt (2005), and Harmer (2007), there are several strategies in adapting the textbook, such as modifying or changing the form of tasks, addressing omission, adding material, and rewriting.

Furthermore, the textbook also helped teachers in managing their lessons in classroom activities. Both teachers received several advantages from textbook such as textbook act as guideline book for teachers, they provide a variety of learning resources, and helped in planning instruction. But implicitly, the reason why teachers used textbooks as guidance was that teachers were anxious not able to complete the materials in the syllabus on the existing curriculum, and finally, teachers were anxious that students could not answer questions on the national exam. This is because the 2013 curriculum had been determined by the central government, started from planning the lesson plans up to textbooks or teaching materials. So, the teachers used the main textbooks to meet the syllabus on the curriculum and merely to make students able to answer the national exam.

In addition, teachers needed a textbook, and they adapted supplement from other materials to make a lesson perfect and interesting (Ansary and Babai, 2003). Therefore, the teacher should have the ability to adapt the textbook to make interesting learning for the student inside the teaching and learning process. This is in line with Richard (2001), the textbook leads to teachers more creative and attractive.

Based on the result, teachers raised some issues about using textbooks inside the teaching and learning process. The problem found by teachers in teaching and learning in classroom activity were materials and activity, language level, and teaching aids.

For the materials and activities teachers preferred to encounter the problem by making some adaptation or used some supplementary materials in teaching such as external books and the internet. Richards and Rogers (1986) suggested that instructional materials are able to give contents specification in detail. They direct teachers on the intensity of coverage and the amount of attention demanded by certain content or pedagogical task. Therefore, the teacher often used supplementary material

Intensive Journal, Vol. 4(1), 2021 
as additional information to make sure students be able to learn more inside the classroom.

Furthermore, Richards and Rogers (1986) stated that an adaptation is a strategy used by the teacher in using a textbook to make materials in the classroom more suitable in a particular context will be used. In this case, the teachers usually used different kinds of tasks and exercises from the external textbook with some other media such as pictures and videos from the internet.

Another finding shows that there was a language difficulty level in the textbook used. One of the teachers claimed that the language level in the textbook was slightly high for their students based on their students' abilities, so the students' got difficulties with it. In this case, the teachers only used a traditional way to explain the book by asking them to open a dictionary and found the meaning of the sentence in the textbook. Sometimes the teacher also presented the book in her own language.

The other aspects that become the main concern of teaching English were related to the media or aids in the teaching and learning process. Teachers found it difficult to obtain, because there were no media available on the textbook they used. To anticipate this difficulty, the teachers sometimes used the internet as a helper or just read the listening transcript orally by themselves. Since the school lacked facilities for media in the teaching and learning process, the teacher sought and made media by themselves.

Hence, the writer can conclude that the materials on textbook and adaptation materials helped the teachers and students in the learning and teaching process to be conducted in classroom activities. Also, it could be a guide in teaching. Thus, teachers should know what aspect can suit students' needs as well as the problem in teaching and learning for the evaluation activity. Besides, teachers should have the option of choose supplementary materials based on their particular needs in their own specific teaching situation. In addition, a professional teacher should attempt to solve the problem faced in using a textbook by themselves to make exciting teaching and learning the classroom.

To develop a syllabus is to determine what will be taught and in what order it will be taught. Designing a syllabus for teaching purposes can be defined as the organizing of selected content into an organized and practical sequence for the purpose of teaching. Curriculum design, according to Munby (1987), is a process of determining the content that has to be taught and structuring it into a teaching syllabus that contains relevant learning units for each student. It contains characteristics such as (a) progressing from known to unknown matter, (b) adequate size of teaching units, (c) a proper variety of activities, (d) teachability, and (e) instilling a feeling of purpose in students' hearts and minds.

Intensive Journal, Vol. 4(1), 2021 
Selected syllabuses represent a significant decision in language instruction during the process of syllabus construction, and it is important that this decision be made as thoughtfully as possible and with as much information as possible. This is accomplished through the belief held by teachers and syllabus designers in relation to language learning theory, which plays a significant role in selecting which sort of syllabus is used.

Once a specific sort of syllabus is selected, all variables to which teachers and syllabus designers must pay attention are classified into two categories by Halim (1976), who divided them into two categories: Nonlinguistic variables include anything from policy to social, cultural, technological, and administrative aspects. Linguistic variables include the linguistic relationship between the language to be taught and the language or languages that students use in their everyday activities.

For ESP programs, in which both language and content are taught in the classroom, such an examination of students' requirements and interests in learning gains is of particular importance and precedes all stages of the syllabus design approach, particularly in the case of language and content instruction.

Aside from the results of the requirements analysis, one important aspect that influences the selection and structure of syllabus content is the type of reference that teachers and syllabus designers can make to students' general language skills. Collaboration with content teachers is required throughout this stage of the organization process in order to provide helpful inputs on instructional objectives, materials, methods, and evaluation procedures.

Based on the information presented above, it can be stated that syllabus design is a logical sequence of three basic stages: 1) needs analysis, 2) content specification, and 3) syllabus arrangement.

(1) Need analysis; (2) formulation of objectives; (3) selection of material, (4) organization of content, (5) choice and organization of learning activities, and (7) decisions on what needs to be evaluated and how to evaluate it are all included in this formulation (Taba, 1962).

\section{INSTRUCTIONAL MATERIAL FOR TEACHING ESP}

Material is regarded as a critical component of any instructional program, and this is especially true for ESP classes. Instructional material includes any and all items that are intended for use by learners and their teachers as a learning resource and that aid learners in the acquisition of facts, skills, or opinions, as well as the development of cognitive processes. It is possible for instructional materials to be either printed or nonprinted, and they can contain everything from textbooks to technology-based resources to other educational materials and assessments. This comprises Web-based

Intensive Journal, Vol. 4(1), 2021 
and electronic textbooks, among other things. According to Cunningsworth, instructional materials serve a variety of functions in language teaching, including serving as a source for presentation, whether oral or written; a source of activities for learners practice and communicative interaction; a reference source for learners on grammar, vocabulary, pronunciation, and other topics; a source of stimulation and ideas for classroom activities; a syllabus where they reflect learning objectives that have already been determined; and a support for teachers.

Particularly in the context of ESP teaching, instructional materials have a purpose other than simply presenting what learners should be educated. Because it is created in accordance with the needs and interests of the learners, it not only acts as a source of language and reference, but it also works as a learning support tool, providing motivation and excitement. It is possible that ESP materials will aim to provide exposure to the specialized genres and registers in ESP to support learning by stimulating cognitive processes and providing a structure and progression for learners to follow, to motivate learners by presenting achievable challenges and interesting content, and to provide resources for self-study outside of the classroom (DudleyEvans, 1998).

It is possible that two difficulties will need to be considered while selecting and designing instructional materials for ESP education; namely, language systems and language uses. Language systems are concerned with grammatical structure, core vocabulary, and the pattern of text arrangement in a given language. Language usage include speaking acts, genres, social interactions, and the use of words for meaning that is special to a certain discipline.

When it comes to scientific and technical writing, grammatical structure and vocabulary are the two components of language that are considered to be of primary importance. According to this theory, even though scientific and technical writing uses the same grammar as ordinary English, specific grammar structures and vocabulary items are frequently utilized in scientific and technical writing. Barbara Barber's study of scientific and technical publications demonstrated that the passive voice is used more frequently in such writing than in ordinary English, and she also identified a number of technical vocabulary items that were more likely to be encountered in such writing (Barber, 1985).

People's interpretations of texts can be tied to top-down approaches to secondlanguage reading teaching and listening comprehension, according to some theories. Top-down techniques urge students to make use of their prior knowledge in order to better understand a text they are reading. He contrasts top-down approaches to comprehension with bottom-up methods, which regard comprehension as a process of decoding successive layers of language from sounds to words and sentences in

Intensive Journal, Vol. 4(1), 2021 
order to arrive at meaning. Background knowledge can take on a variety of shapes and forms when viewed from the top-down perspective, including knowledge about the topic of the dialogue, the circumstance, and the script, to name a few examples (Richards, 2001). It can also contain knowledge of text structure patterns, if applicable. Martinez argues in favor of a method of teaching reading in ESP that focuses on improving pupils' awareness of macro patterns in text rather than on rote memorization.

There are several types of linguistic inquiry in ESP that demonstrate a functional view of language (language usage), including descriptions of speech actions and genres, as well as social interaction formulae utilized in professional, business, and academic situations. It can also be observed in attempts to determine how words are employed in particular fields (such as economics or law) to represent notions that are unique to that subject.

Speech act descriptions are concerned with the communicative intentions of particular speakers or authors, and they are defined by the goals for which the speaker employs the language, for example, to make a request, to apologize, and to report on a situation. Pragmatics is the study of speaker intent and what speakers mean when they use a certain linguistic in a particular situation, and speech acts are a fundamental term in this subject. The ideas regarding speech acts serve as the foundation for the functional syllabus.

A genre is defined as a class of language use and communication that happens in specific societies and is distinguished by its specificity. A genre is given a name by the group of people who are involved in its creation. ESP researcher Dudley-Evans credits Tarone et al. with the discovery of the term genre, which they used to describe a study that looked at the employment of active and passive forms in journal papers in the field of astronomy. For ESP learners, genres are consistent patterns of communication that are based on the established practices of those in the organizations and communities in which they wish to become involved. Learning how to communicate in the genres that are popular in the target communities is viewed as one way that ESP can assist learners in becoming accepted into those communities.

When it comes to meeting the needs of students, the components of the language system and language use will be extremely important. They must be carefully chosen, arranged, and sequenced based on the content items on the syllabus in order to be effective.

Intensive Journal, Vol. 4(1), 2021 


\section{ASSESMENT IN TEACHING ESP}

The act of assessing is referred to as assessment. It is the assessment of a student's performance in a course. It is the process of determining the extent to which instructional objectives have been met. It acts as a kind of feedback on student learning and, consequently, on the success of the teaching and learning process. According to Dudley-Evans and St. John (1998), assessment serves two primary purposes: to obtain feedback to aid in learning and to establish comparable measures of ability.

Assessment quantifies the benefits of education. Similarly, Richards \& Renandya (2002) argue that evaluation generates an observable opinion of a teacher's effectiveness. Assessment is a tool for learning in ESP. It can provide learners with a sense of accomplishment and a sense that the teacher's grading system corresponds to the skills and knowledge taught. Additionally, they state that assessment provides benefits such as reinforcement, confidence building, engagement, and strength building.

Assessment in ESP courses is primarily concerned with facilitating learners' performance of specific communicative tasks, providing feedback on learning, confirming which skills learners have mastered and highlighting those that require additional attention, encouraging learning, and monitoring progress. Douglas (2000, p.10) states that evaluation is a staged language usage event in which the student's talents and knowledge in specialized domains are optimally assessed.

As language capacity relates to what a learner can do in and with the target language, what matters most in ESP evaluation is whether learners can communicate in and with the target language in order to accomplish their goals, to understand and be understood, and to convey their messages in English. Thus, the areas of ESP assessment are related to specific disciplines in terms of content, themes, and topics, and involve a greater degree of technical language, which, in addition to its communicative function, enables learners in a particular academic, professional, or vocational field to convey meaning more precisely. Any ESP evaluation can be categorized as a performance assessment since it is designed to determine the abilities required to function successfully in the target language given the context in which it is used and the interplay between language knowledge and particular purpose content knowledge.

The other distinguishing feature of ESP assessment is its emphasis on presenting learners with tasks that require them to read, listen to, and write. Speaking and writing the target language, as well as assessing their ability to do so. The key to this assessment is to offer learners with tasks that are similar in some respects to the types of tasks they could encounter in real life when using the language. In this regard,

Intensive Journal, Vol. 4(1), 2021 
the ESP method to testing should be founded on an examination of learners' target language usage scenarios and on professional understanding of English for real communication. This is consistent with the ESP test criteria, which state that comprehensive coverage of typical real-life communication events results in the selection and creation of appropriate test tasks, facilitates more integrated and thematically linked assessment, in which test tasks authentically characterize the learners' reality, and, finally, results in higher test validity (Douglas, 2000, p.10).

\section{REFERENCES}

Halim, A. (1976). Decision-making in Language Course Design 'in Wilson, G.H. (ed.) Curriculum Development and Syllabus Design for English Teaching Singapore. SEAMEO Regional English Language Center

Barber, C. L. (1985). Some measurable characteristics of modern scientific proses. In J. Swales (Ed.), Episodes in ESP (pp. 1-16) Hemel Hempstead:Prentice Hall.

Basturkmen, H. (2006). Ideas and options in English for specific purposes. New Jersey: Lawrence Erlbaum Associates, Inc., Publishers

Chaput, P. P. (1993). Revitalizing the Traditional Program. In: Kreuger and Ryan (eds.) Language and Content: Discipline- and Content-Based Approaches to Language Study.

Lexington, MA: D. C. Heath.Crandall, J. \& Richard, G.T. (1990). Content-Based Instruction in Second and Foreign Languages. In: Amado Padilla, Hatford H. Fairchild and Concepcion Valadez (eds.) Foreign Language Education: Issues and Strategies. Newbury Park, CA: Sage.

Dudley-Evans, T. (2001).Team-teaching in EAP: Changes and adaptations in the Birmingham approach.In J. Flowerdew\& M. Peacock (Eds.), Research perspectives on English for AcademicPurposes. Cambridge: Cambridge University Press, page 225-238

Dudley-Evans, T \& St John, M J. (1998). Development in English for Specific

Purposes.Cambridge: Cambridge University Press, page 1; Smoak, R. 2003. What is English for Specific Purposes. English Teaching Forum, 41(2).

Douglas, D. (2000). Assessing Language for Specific Purposes. Cambridge: Cambridge University Press

Flowerdew, J., \& Peacock, M. (2001a). The EAP curriculum: Issues, methods and challenges. In J. Flowerdew\& M. Peacock (Eds.), Research perspectives on English for Academic Purposes.(pp. 177-194). Cambridge: Cambridge University Press.

Intensive Journal, Vol. 4(1), 2021 
Eskey, D. (1997). Syllabus Design in Content-Based Instruction. In: Snow and Brinton (eds.) The Content-Based Classroom. New York: Longman. Findley, C. A. \& L. A.

Nathan. (1980). Functional Language Objectives in a Competency-based ESL Curriculum. Tesol Quarterly, 14(2).

Genesee, F. (1994). Integrating Language and Content: Lessons from Immersion. Santa Cruz, CA: National Center for Research on Cultural Diversity and Second Language Learning,

Hutchinson, T. \& Waters, A. (1993). English for Specific Purposes. Cambridge: Cambridge University Press.

Hutchinson, T \& Waters, A. (1987). English for Specific Purposes, A Learningcentered Approach. Cambridge: Cambridge University Press

Krahnke, K. (1987). Approach to Syllabus Design for Foreign Language Teaching. New Jersey: Prentice-Hall.

Mackay, R. \&Mountford, A. (Eds.). (1978). English for Specific Purposes: A case study approach. London: Longman.

Met (ed.). (1998). Critical Issues in Early Second Language Learning. Glenview, IL: Scott-Foresman-Addison Wesley

Mulyasa, E. (2004). KurikulumBerbasisKompetensi: Konsep, Karakteristik, Dan Implementasi. Bandung: RemajaRosdakarya

Munby, J. (1987). Communicative Syllabus Design.Cambridge: Cambridge University Press.

Nunan, D. (1988). Syllabus Design. Oxford: Oxford University Press. 